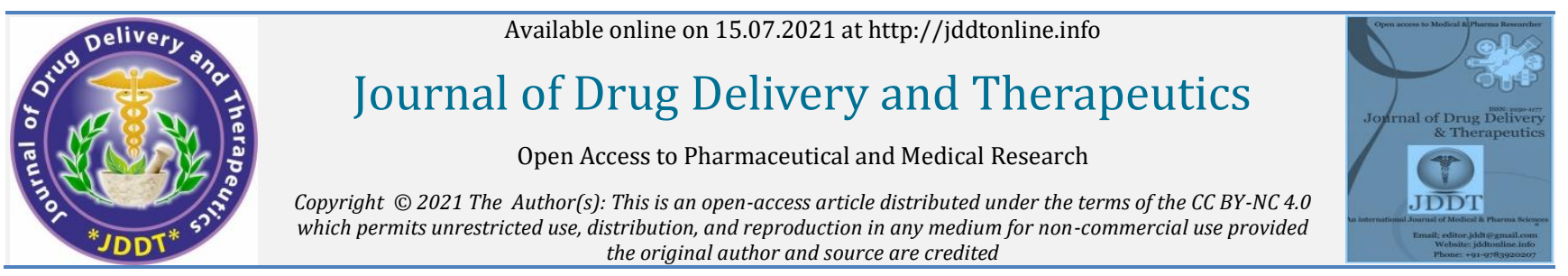

Open Access Full Text Article the original author and source are credited

Review Article

\title{
Understanding the drug delivery through nails: a comprehensive review
}

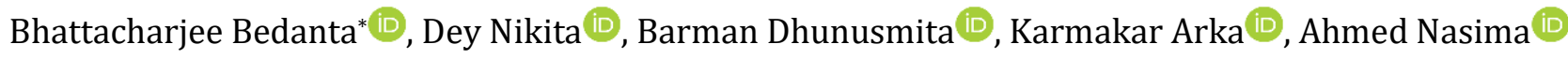 \\ Department of Pharmaceutical Sciences, Faculty of Science and Engineering, Dibrugarh University, Dibrugarh-786004, Assam, India.
}

\section{Article Info:}

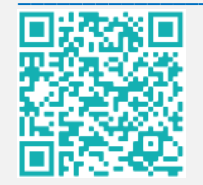

\section{Article History:}

Received 11 May 2021

Review Completed 24 June 2021

Accepted 29 June 2021

Available online 15 July 2021

\section{Cite this article as:}

Bhattacharjee B, Dey N, Barman D, Karmakar A, Ahmed N, Understanding the drug delivery through nails: a comprehensive review, Journal of Drug Delivery and Therapeutics. 2021; 11(4):116-131 DOI: http://dx.doi.org/10.22270/jddt.v11i4.4941

\section{*Address for Correspondence:}

Bhattacharjee Bedanta, Department of Pharmaceutical Sciences, Faculty of Science and Engineering, Dibrugarh University, Dibrugarh786004, Assam, India

ORCID ID: https://orcid.org/0000-0002-8481-3214

\section{Abstract}

The nail unit is the largest cutaneous musculo-skeletal appendage. The management of nail disorders is an onerous task owing to the disease manifestations and anatomical structure of the nail plate. The topical treatment of nail infections/disorders has been a centerpiece of nail research in the past few decades as it offers a much safer and focused alternative to conventional oral therapy. However, transungual delivery had its challenges. This necessitated a lookout for novel approaches that enhanced treatment efficacy and reduced treatment time. Moreover, curing the nail condition using topical delivery has been challenging due to the lack of a validated animal model to determine the efficacy of the formulation and to establish a mathematical model that can help in predicting the desirable attributes of the formulation and permeation of various molecules through the nail plate. This review is based on publications retrieved by a selective search in PubMed. The purpose of this review is to provide an overview of nail anatomy and its disorders, factors affecting nail delivery, diagnostic procedures, current approaches, and promising approaches to treat nail infections/disorders including nail lacquers and the role of permeation enhancers, in-vitro models. This review also covers current available treatments and treatments under clinical trial.

Keywords: Musculo-skeletal, Nail infection, Transungual, Mathematical model, In-vitro models.

\section{INTRODUCTION}

The nail unit signifies the bulkiest and a rather complex skin accessory organ pinpoint on the dorsal surface of the tips of fingers and toes and is a flexible appendage for protection, dexterity, and sensory functions. The nail is constructed of keratinized squamous cell functions. Anatomically, the mature nail organ comprises of mainly four epithelial elements: the nail plate matrix; the nail bed which is steadily connected to the distal phalanx plate; the hyponychium which structures a common barrier at the physiological point of separation of nail out of bed; the eponychium, which represents the underside of the proximal nail fold and is important for cuticle production 1 . The nail unit also possesses an abundant vascular network to ensure adequate blood supply. The nail primordia start development at the tips of toes and fingers from the $9^{\text {th }}$ week onwards of the gestation period. Nail disorders can make an appearance at any age. They include disorders that can be prevalent and nonlethal to subtle yet lethal. The majority of nail abnormalities are caused by infections, $15 \%$ by inflammatory or metabolic illnesses, and $5 \%$ by malignancies and pigment problems 2 . Dealing with nail disorders has been challenging as oral therapies have numerous limitations for instance a lack of patient compliance, a high risk of recurrence, significant adverse effects, and contraindication. Also topical delivery in healing nail conditions is partially difficult in curing the nail conditions consequently complex nail structure displaying a complicated blockage and the inability to determine the appropriate method for delivering a medication to the nail bed ${ }^{3}$. The present review deals with the literature covering nail anatomy, nail disorders, diagnosis, in-vitro models, and advances in treatment.

\section{NAIL ANATOMY}

The nail is a one-of-a-kind barrier made up of several strands of keratin bound together by disulfide bonds that acts like a hydrogel and has a lightweight nature with a specific thickness ${ }^{4}$. The human nail is about 100 times greater in thickness in comparison with the stratum corneum, making it the body's hardest boundary structure 5,6. The aesthetic appeal of nails is also significant. Unlike hair, fingernails grow at a constant rate of about $0.1 \mathrm{~mm}$ per day or $3 \mathrm{~mm}$ per month. Toenails develop at around half to one-third the rate of fingernails. A fingernail regenerates in 4-6 months, while toenails take 8-12 months or longer to regenerate. Because of its structure, it has a defensive feature. It is made up of 25 layers of fragile, dead, and keratinized cells, each measuring $0.01 \mathrm{~mm}$ in thickness. The nail unit refers to the nail and its parts as a whole 7 . The plate of the nail grows from the matrix, arises from the crease of the proximal nail, and is retained in place by the lateral nail folds. The nail plate shields the nail bed from damage and separates from it at the hyponychium. It is discovered that the plate of nails is thin, somewhat elastic, rigid, transparent, and convex in form. Intercellular attachments, desmosomes, and membrane coating granules keep these cells intact ${ }^{8}$. The low lipid content of the nail layer, along with its molecular composition of keratin molecules communicating across 
disulfide linkages, gives it a hydrogel-like behavior, separating it from other body barriers 9. The parts of nail assembly are hyponychium, nail matrix, nail fold, nail plate, nail bed, and onychodermal band Figure 1.

\section{Nail matrix and lunula (nail root)}

The matrix of the nail is barely the living component of the nail apparatus, which consists of germinative epithelial tissue whose cell division gives rise to the plate of nails. It is found under the skin at the proximal tip of the nail ${ }^{10}$. The tissues under the nail are separated into two groups: the matrix $(15-25 \%)$ and the nail bed (75-85\%). In certain digits, the apex of the matrix is visible as the lunula. In certain cases, the crease of the proximal nail completely obscures it. The proximal element covers approximately half of the space between the nail fold and the distal interphalangeal joint's central crease. Reardon recommends choosing a position 75 percent of the way to the distal interphalangeal joint as the location for this marker is necessary for nail unit excision ${ }^{11}$. The lunula is a pale "halfmoon" that can be found on the index finger is less visible in the digits on the ulnar side. The matrix gives rise to all or much of the plate of the nail. On functional grounds it is feasible to create a distinction between the distal and proximal matrix, it is said that in the nail plate, $50 \%$ of the proximal nail matrix contributes $81 \%$ of the cell numbers 12 .

\section{Nail bed (ventral matrix and sterile matrix)}

The bed of the nails is a very thin epithelium to which the nail plate adheres and slides during its development ${ }^{12}$. The nail bed runs from the lunula distal margin to the hyponychium. A set of epidermal ridges that run the length of the skin extending to the lunula can be seen after the avulsion of the nail. A complementary series of ridges can be seen on the bottom of the plate of the nails, as a result, the nail was guided up the nail bed as if on tracks. The nail bed's tiny vessels are all aligned around the same axis. The nail bed is adorned with a low degree of proliferation and a keratin supplement that lacks the terminal separation keratins, K1 and K10, found in normal skin. The nail bed's dermis is scant, with slight fat, hard collagenous conformity to the underlying periosteum, and neither sebaceous nor follicular appendages are present ${ }^{11}$. In-vivo magnification allows that near the nail bed's distal edge sweat ducts have been seen ${ }^{11}$.

\section{Hyponychium}

The hyponychium is the region under the free edge, where the nail plate begins to separate from the nail bed 4 . A crack is formed by the hyponychium and an elongated free nail. This is a repository for scabies, antigens, and microbes; it is significant in surgery and infection spread. It forms a protective seal around the nail bed.

\section{The cuticle (eponychium)}

The proximal nail fold of the nail plate has an epidermal layer that reaches up to the dorsal side ${ }^{13}$. Cuticle failure makes the proximal nail fold's defensive function more complex, indicating that the first barrier has been broken. Cuticle regrowth is a clear sign of an inflammatory process's resolution. Inflammation of the folds of the nails and changes in the plate of the nail surface are common side effects of manicures, and cuticle removal should be avoided.

\section{Nail folds}

Nail folds, which are skin structures that enclose the nail plate at its lateral and proximal ends, are made up of folds on the proximal and lateral sides. The cuticle stretches from the nail fold at the proximal end acting as a physical barrier against exogenous materials entering the nail ${ }^{4-}$
Lateral nail folds: The cushioned cutaneous lateral margins of the nail are made available by lateral nail folds. In the toes, they are usually more common than in the digits, which is associated with the help of their participation in the nail's strict adherence to the bed of the nail.

Proximal nail fold: The nail fold of the proximal end is a skin lip formed during week 14 of embryogenesis where the nail's origin forms a pocket on the digit's dorsum. It adheres to the nail plate's dorsal side and conceals the whole or a portion of the matrix of the nail, clinically known as the lunula. It joins with the plate of the nail to form a protective coating over the matrix, which, if weakened, can cause permanent nail scarring. This protection also includes UV protection to complement the natural UV protection provided by the nail plate ${ }^{14}$. The matrix is the only subungual location where functional melanocytes can be found, and UV protection can help to minimize the risk of cancer. The proximal nail fold also works in tandem with the cuticle to form a barrier against irritants, solvents, and other agents that could disrupt matrix function and, as a result, nail formation.

\section{Nail plate}

The plate of the nail is the most visible portion of the nail apparatus. It is a thin stratum (0.25-0.6 mm) consisting of around 25 layers of death, keratinized, and flattened cells that are tightly bound to one another 15 . The plate of the nail is an updated stratum corneum with a keratinized laminated structure that guards the nail matrix and bed. When studied histochemically with silver stains, by optical coherence tomography, by ultrasound, and by electron microscopy, the laminated shape can be seen 16,17 . While its physical features are compatible with a bi-laminar structure, it is commonly thought to be tri-laminar. The ventral aspect of a tri-laminar structure might have evolved by superficially adherent material provided by the nail bed. This is provided as a reason for the rise in density and thickness as it expands distally ${ }^{18}$. It also has linear ridges that match up with flattering ridges on the nail bed to which it is bonded. Both the transverse and longitudinal axes of the plate of the nails are curved. This causes it to be inserted in the lateral and proximal edges of the nail, providing good attachment and making the free edge a valuable weapon. Toes have a more prominent characteristic than fingertips. The lateral margins of the matrix and nail around the terminal phalanx of the great toe stretch about halfway around it. This gives the foot the necessary strength. The nail plate's upper surface is relatively flat, with a non-constant quantity of ridges that vary with age. The fold of the proximal nail side, which is termed the lunula, is used as a reference structure to calculate the rate of growth of the plate of the nail ${ }^{19}$.

\section{Onychodermal band}

The nail bed's distal edge, known as the onychodermal band, has a different color than the rest of the nail bed 20 . This is typically a 1-1.5 mm transverse band with a darker pink or brown color. It is color or appearance may change because of disease or compression, affecting vascular supply. The onychocorneal band is the first line of defense against materials penetrating under the nail plate. In general terms, the matrix of the nail is responsible for the nail plate creation, residing on the bed of the nail, and is framed and ensheathed by the nail folds and the hyponychium ${ }^{4,21}$. 


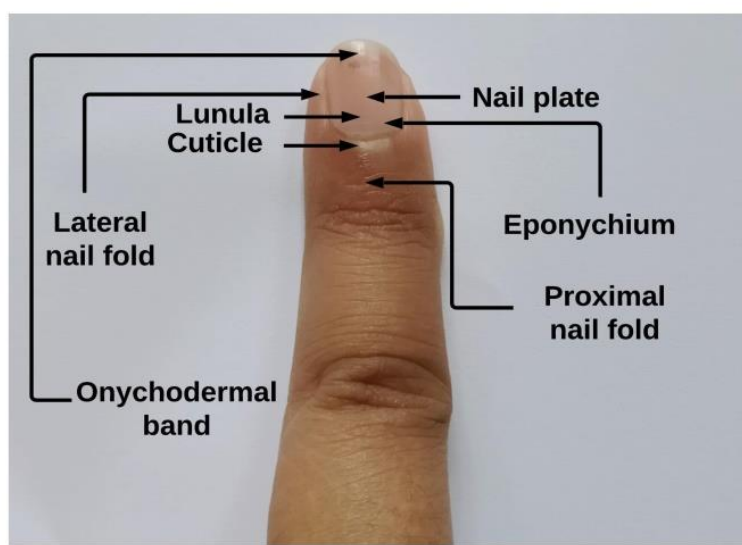

Figure 1: Structure of human nail finger.

\section{NAIL RELATED DISORDERS}

Nail diseases range from pigmentation or discoloration to excruciating and crippling conditions resulting in atrophy, inflammation, and brittle broken nails 22 . Nail diseases account for around $10 \%$ of all dermatological disorders and are common among the elderly ${ }^{23}$. This high frequency is due to several reasons, including poor circulation and the presence of a chronic systemic condition (e.g. diabetes mellitus), neoplasm, changes in foot biomechanics, and a weakened immune system 24,25 . It is becoming increasingly clear that nails and systemic diseases are inextricably linked, and that nails can offer important diagnostic hints for the underlying pathologic disorder ${ }^{25}$. Nail problems may harm a patient's quality of life. General problems include pain, trouble walking, difficulty wearing shoes, fear of spreading illness, and social humiliation. The potential to recognize both natural and pathologic variations in the nail allows for more effective care and diagnosis of these common issues.

\section{Onychomycosis}

Onychomycosis is a fungus that attacks the nails. Dermatophytes, yeasts, and molds are responsible for the infection. Our nails, hair, and skins are more vulnerable to dermatophyte fungi, which are liable for up to $80 \%$ of fungal infections. Onychomycosis is a nail fungal infection that affects $10-40 \%$ of the population. Genetic predisposition to onychomycosis, diabetes mellitus, and nail injury, as well as a suppressed immune system, are the most likely causes. Excessive sweating, ill-fitting socks, and wet feet are all aggravating factors. Thickening, discoloration, and cracking of the nails are all symptoms of fungus infections, which cause inflammation and pain. Four distinct forms of onychomycosis result from various fungi infesting themselves in different ways.

i. Distal lateral subungual onychomycosis: Fungi spread via the distal subungual area, hyponychium, and lateral nail groove. The nail plate develops yellow longitudinal lines, and the nail bed thickens or hardens in many instances (hyperkeratosis).

ii. Proximal subungual onychomycosis: Infection in the proximal nail plate caused by penetration from the nail proximal folds or nail cuticle is the least common form. It has a distinctive trait of change in color of the nails as white streaks that appear close to the fold of nails and can spread to other areas over time.

iii. Superficial onychomycosis: By infecting the nail plate's dorsal surface, it is mostly limited to toenails. White streaks or specks appear on the nail layer, which often becomes more friable and powdery in texture. iv. Endonyx onychomycosis- Infection by a fungus that enters the nail plate through the free margin, causing a milky white blemish and leaving the nail plate opaque. In this form of infection, between the nail bed and the nail plate, there is no separation or thickening (hyperkeratosis) ${ }^{15}$.

\section{Paronychia}

Inflammation of the lateral and proximal nail folds is caused by this infection. It may be acute or chronic. Staphylococcal bacteria cause the acute type, which damages the cuticle and nail folds, causing discomfort and inflammation. Irritant reactions to environmental pollution or alkali induce chronic paronychia. The nail fold swells, creating ideal conditions for the growth of common bacteria, exacerbating the disease 26 .

\section{Nail psoriasis}

Psoriasis is a skin condition characterized by raised red patches that cause inflammation and discomfort. The nail matrixes has pitting and deep transverse furrows, while the bed of the nail having distinctive yellow-red nail discoloration that looks like a drop of blood or oil beneath the plate of the nail and leads to skin thickening underneath the nail. The nail plate's hardness and elasticity were lost, resulting in the nail loosening and cracking 26.

\section{Nail plate overgrowth (onychogryphosis)}

It is normal in the elderly due to their failure or lack of hygiene or nail clipping. It allows the plate of the nail to thicken and curl, giving it a 'claw-shaped' appearance. Thickened nails can cause discomfort by pinching the skin. Subungual hemorrhage may arise because of excessive trauma, particularly if you have the peripheral vascular disorder or diabetes 26 .

\section{Spoon nails (koilonychias)}

It's a condition that allows the nail's free edge to become everted, like a spoon. It affects a large number of children. Nail-biting causes several transverse grooves on the nail plate and cold contact causes blue-and-white fingertips from Raynaud's disease or related collagen vascular disorders. Some nail disorders include leuconychia, which causes white streaks or stripes on the nail because of trauma. Brittle and rough nails that tear quickly or often cut vertically are symptoms of an infection known as onychorrhexis. Onychotrophia is specified by nail plate atrophy 27.

\section{Pseudomonas bacterial infection}

This can happen between the nail bed and nail plate, as well as between an artificial nail layer and the nail plate. The classic 'green' discoloration of this form of infection has led many people to think it is mold. Mold, in reality, is not a human pathogen ${ }^{28}$. The discoloration is caused mainly by iron compounds and is a by-product of the infection. Pseudomonas thrives in wet environments, where it feeds on dead tissue and bacteria in the plate of the nail while allowing it to expand. The nail plate will darken and weaken under an artificial coating for this infection. The finer the discoloration, the deeper the bacteria have penetrated the nail plate membranes. The same discolorations will occur if the bacteria enters between the nail bed and the nail plate, and the nail plate can even rise from the nail bed 29 .

\section{Fungal or yeast infection}

Onycholysis (nail plate separation) is a symptom of this infection, as is visible debris below the plate of the nail. It is usually pale yellow and also changes seen in the shape and structure of the nail. The nail plate is mainly made up of keratin protein, which the fungus digests. Chemical material 
accumulates beneath the nail plate as the infection spreads and changes in the nail color take place. Involvement of other contagious agents may be there, and if not medicated properly, the nail plate could detach from the nail bed 30 .

\section{Tinea unguis}

It is the nail ringworm and is marked by distortion, thickening of the nail, and ultimately resulting in nail plate amputation 31 .

\section{Onychatrophia}

Onychatrophia is the loss of luster, shrinking, and occasionally complete shedding of the plate of the nail. This nail irregularity may be because of an injury or a disease 31 .

\section{Onychogryposis}

Onychogryposis is a condition characterized by claw-like nails with nail plate thickening that is mostly the product of trauma 32 . This sort of plates of the nail will bend upward, pinche the bed of the nail, and surgical action is required some time to ease the discomfort.

\section{Onychorrhexis}

Brittle nails with longitudinal splits, peeling, and/or vertical ridges are known as onychorrhexis. This irregularity in the nail may be because of heredity, also the use of heavy solvents in the workplace or at home, such as household cleaning solutions. While treatments with oil or paraffin will hydrate the nail plate ${ }^{33}$.

\section{Leuconychia}

It appears as white marks or stainson the the nail plate and is produced by tiny bubbles of air stuck in the nail plate layer because of trauma. This disease may be inherited and there is no need for medication because the spots will fade with the expansion of the nail plate ${ }^{31}$.

\section{Beau's lines}

Nails with horizontal lines of darkened cells and linear depressions are shown in this situation. This disease is exacerbated by some disruption in the protein production of the nail plate may be because of accident, sickness, starvation, or any significant metabolic condition, chemotherapy, or other harmful events ${ }^{34}$.

\section{Hematoma}

It mainly occurs due to the destruction of the nail plate. That can be anything from catching a finger or toe in the car door to rubbing from ill-fitting or too-tight shoes to a sporting accident. A hammer can also trigger a hematoma! Owing to the damage, the nail bed will bleed, and the blood will get stuck between the nail bed and the nail plate. A hematoma may also be a sign of a broken bone. Because of the excessive rubbing between the shoes and the toenails, many people who engage in athletic events develop hematomas. Since blood attracts fungi and bacteria, hematomas can result in nail plate fragmentation and infection. If the clotting of blood becomes sore for several days, the nail plate can need to be removed so that the nail bed can be cleansed 35 .

\section{Melanonychia}

Melanonychia are pigmented vertical bands that develop in the matrix of the nail and are mostly referred to as "nail moles". A sudden shift in the plate of the nail may indicate the presence of malignant melanoma or a lesion. Dark spots are a fairly common trait in people with dark skin ${ }^{35}$.

\section{Pterygium}

Pterygium is the internal advancement over the nail plate with the skin caused by damage to the matrix from a surgical operation or an intense cut to the nail plate. Because of the formation of scar tissue, pterygium causes the degradation of the nail plate. Generally, cortisone is used to slow the progression of scar tissue. Instead of attempting to extract pterygium ${ }^{36}$.

\section{Pterygium inversum unguis}

It's an acquired disorder characterized by live tissue tightly clinging to the nail plate's underside, which includes a blood supply and nerves, and forward development of the hyponychium. Systemic, genetic, and allergic reactions to acrylics or solvents are also possible causes ${ }^{36}$.

\section{Vertical ridges}

This is often a sign of aging, although it is not limited to the frail or the elderly. In a 'rail and groove' result, the nail plate grows forward on the nail bed, similar to how a train rides on the tracks. As we mature, the natural oil and moisture levels in nail plates decrease, resulting in the rail and groove effect ${ }^{37}$.

\section{Nail patella syndrome}

It is an unusual genetic mutation that causes nail and skeletal distortion (along with a variety of other associated anomalies) in about 2.2 among 100,000 individuals. It is inherited as a basic autosomal dominant trait in the $\mathrm{ABO}$ blood group. It also ensures that there are no unaffected carriers, and nail-patella syndrome cannot miss a generation. Nail patella syndrome is thought to be caused by a sporadic gene mutation in circumstances where there seems to be no prior family history of the condition. Once nail-patella syndrome has been identified in a household, the chance of passing the condition on to offspring is $50 \%$ for each birth, regardless of the child's gender, with females being affected $10 \%$ more often ${ }^{37}$.

\section{FACTORS AFFECTING BARRIERS IN DRUG DELIVERY}

\section{Size of diffusing molecule}

Drug penetration into the nail plate is inversely proportional to molecular size. Diffusion will be harder through keratin meshwork as molecular size increases 38 .

\section{HLB value}

As the lipophilicity of a substance increases, the permeability coefficient decreases to a certain stage, after which a rise in lipophilicity results in an increase in permeation in the nail. Though, pure alcohol's permeability coefficient will be five times lesser approximately than diluted alcohols. In the case of aqueous formulation, nails swell water and are trapped into the nail plate. As the keratin network expands, it causes larger pores to form, allowing diffusion of the molecules more easily ${ }^{38}$.

\section{Degree of ionization}

Ionic compounds are less permeable to nail plates than their non-charged counterparts with permeability coefficients 39.

\section{Nature of vehicle}

Water hydrates the nail layer, causing it to swell. Assuming the nail plate or bed is a colloidal gel, swelling causes an increase in the distance between keratin fibers, greater pores through which permeating molecules will diffuse, and hence 
increased molecule permeation. Drug absorption into the nail plate should reduce by substituting water with a nonpolar solvent that does not wet the nail ${ }^{40}$.

\section{Presence of dorsal layer}

Overlapping cells are the most effective barrier to drug perforation between the nail layer. Drug permeability improves when the layer is completely removed, such as by chemical etching and debridement with 30-40 percent phosphoric acid or the usage of the enzyme keratinolytic ${ }^{41}$.

\section{Effect of nail constituents during drug binding}

Keratin is considered to have a permeation index of about 5 , meaning it is positive and negative charge at $\mathrm{pH}$ levels below and above this. As a result, depending on the charge of the molecules, they can bind or repel them. This may explain why ionic compounds have a lower nail permeability. Drug binding to keratin lowers permeant availability, lessens the concentration gradient, and thus restricts deep penetration 41.

\section{Formulation effect}

Weak acids and bases' degree of ionization is affected by $\mathrm{pH}$, which reduces the permeability of these acids and bases through nail plates. It has an effect on their solubility in preparation, partitioning into the nail layer, and interactions with keratin. Hydration of the nails, the solubility of drugs in the formulation, and drug compartment on the nail plates are all affected by the solvent. DMSO increases permeability 41 .

\section{DIAGNOSTIC TOOLS FOR NAIL DISORDERS}

\section{Nail biopsy}

The nail biopsy is a valuation method for determining the cause of a clinically unclear nail disease that is not diagnosed by experience, diagnostic criteria, or usual mycology ${ }^{42}$. Nail biopsy not only gives diagnostic, prognostic, and etiologic detail but also helps in the analysis of pathogenesis of nail disease ${ }^{43}$. Nail biopsy is particularly helpful in treating psoriasis, lichen planus, longitudinal melanonychia, trachyonychia, and nail tumors 44 . It is used in onychomycosis diagnosis when the culture yield or microscopic of fungi is poor, often after repeated sampling 45 . A nail biopsy aims to make an accurate diagnosis of nail pathology with a quick, safe surgical procedure while preventing pain or discomfort 42 . For every patient, a nail biopsy is not mandatory. But when required there are certain necessary preconditions to be contented.

\section{Methods}

Punch biopsy, excision biopsy, longitudinal biopsy are all methods for nail biopsy. Any anatomical portion of the nail unit, such as nail fold, nail bed, nail plate, matrix, can be accessed with excision or a punch biopsy. Longitudinal nail biopsy provides the most histopathological detail but is not commonly used due to the risk of scarring. A common method of nail biopsy along with site to be biopsied for nailrelated disorders was compile in Table 1.

Based on the location where it is being drawn from, nail biopsy can be classified as follows:

\section{Nail plate biopsy}

The simplest and least painful procedure is nail plate biopsy, which involves separating a portion of the nail plate (onycholysis or not) and sending it for histopathologic study 43. It provides insufficient histopathological information but is helpful in possible cases of nail psoriasis, onychomycosis, and warts. The use of nail plate biopsy in systemic illness has also been investigated thoroughly 46 .

\section{Nail bed biopsy}

Nail bed biopsy is used to differentiate between two or more disorders that have a common clinical pattern, such as subungual hyperkeratosis or onycholysis, stain in the nail bed, or other painful nail bed injury. It may be a punch biopsy or elliptical excision (longitudinally oriented). The recovery of nail bed after surgery is usually uneventful, and the occurrence of scarring and onycholysis are rare ${ }^{42}$. In cases of nail bed tumors, such as glomus tumors, a nail bed biopsy may be helpful 47 .

\section{Nail fold Biopsy}

Nail fold biopsy can be performed on the lateral or proximal nail folds region, and is used to diagnose nail fold inflammation, benign or malignant tumors in the nail folds, and paronychial dermatoses, It may be a punch and shave biopsy, elliptical excision or en bloc excision (only proximal nail fold) ${ }^{48}$. To avoid accidental injury to the underside of the nail bed or matrix, a nail spatula should be inserted under the concerned fold before any excision.

\section{Nail matrix biopsy}

Nail matrix biopsy is used to investigate the matrix cause of benign nail matrix lesions (glomus tumor), malignant lesions (melanoma), accquired nail plate defects such as onychorrhexis, punctate leukonychia, or pitting. The methods used are tangential (shave) excision, elliptical (horizontally oriented) excision, and punch excision (equal or less than $3 \mathrm{~mm}$ ) ${ }^{49}$.

\section{Longitudinal nail biopsy}

Longitudinal nail biopsy is usually carried out when it is necessary to sample the whole nail unit 50 . To ensure full recovery, the resulting defect must be sutured. It is a very useful method to diagnose larger lesions that are asymmetrically located over the infected nail. This method has proven very useful in academics because it samples indicative areas of each section of the nail unit. However, since it is a potentially scarring technique, its diagnostic use is limited. When taking a biopsy, it is essential to soften nail plate specimens before processing them. Various agents such as cedarwood oil, $3 \%$ phenol, and chitin-softening solutions composed of acetic acid, chromic acid, mercuric chloride, and 95\% ethanol have been prescribed for this purpose ${ }^{46}$. The possible reported complication with nail biopsy includes secondary inflammation, bleeding, onycholysis, scarring of the nail bed, malalignment of the regrowing nail axis, a decrease of nail diameter, or development of nail spicules 46 . 
Table 1: Location and methods of nail biopsy for nail-related disorders

\begin{tabular}{|l|l|l|l|}
\hline S. No. & Disease conditions & $\begin{array}{l}\text { Region to be } \\
\text { biopsied }\end{array}$ & Methods of biopsy \\
\hline 1. & $\begin{array}{l}\text { Suspected onychomycosis (lateral and distal subungual } \\
\text { onychomycosis or Total dystrophic onychomycosis) }\end{array}$ & $\begin{array}{l}\text { Onycholysis nail } \\
\text { plate }\end{array}$ & Nail plate biopsy \\
\hline 2. & Onycholysis, subungual hyperkeratosis & Hyponychium & Nail bed biopsy (excision or punch) \\
\hline 3. & Leukonychia & Intermediate matrix & Nail matrix bed (excision or punch) \\
\hline 4. & Splinter hemorrhages, salmon patch, onycholysis & Nail bed & Nail bed biopsy (excision or punch) \\
\hline 5. & Beau's lines, pitting, and eonychorrhexis & Proximal matrix & Nail matrix bed (excision or punch) \\
\hline
\end{tabular}

\section{Optical coherence tomography}

Optical coherence tomography operates by emitting infrared light, measuring its reflection, and imaging the intensity as a function of the material representing the signal 51 . The resolution of an optical coherence tomography is greater than that of high-frequency ultrasound, allowing it to detect subtle variations that ultrasound cannot, as well as providing more detail about the nail unit 52 . Up to $2 \mathrm{~mm}$ penetration depth, it can produce real-time images and a resolution of $10 \mu \mathrm{m}$. Optical coherence tomography is wellestablished in human skin diagnosis, but it is only in its early stages in the study of nail disorders ${ }^{53}$. In the principle of optical coherence tomography, the power of light to interact with itself (i.e. the ability to intensify or blur itself ("constructive" and "destructive" interference, respectively) can be measured using a Michelson interferometer. A beam splitter (half-transparent mirror) divides light into two directions. The light directed at the mirrors is mirrored, recombined, and detected at the beam splitter. Interference between the two reflections is only possible when the path lengths of the two arms are aligned within the light source's so-called coherence length 54 . The spectral width of light determines the coherence length-a wide optical spectrum corresponds to a short coherence length, whereas a narrow optical spectrum corresponds to a long coherence length. Also, very large variations in path length can cause interference when using a light source with a long coherence length. When using a light source with a short coherence length, interference occurs only when the two path lengths are matched within the light's coherence length, which can be a few micrometers 55 . This effect is used in optical coherence tomography to differentiate between signals from different depths of the sample. When one of the Michelson interferometer's mirrors is replaced by a biological sample, as shown in, each location of the scanning mirror corresponds to the signal captured from a thin slice of the sample. In other terms, it becomes possible to pinpoint the source of the reflection. The thickness $\delta z$ of the signalcontributing slice is equal to the system's depth resolution and is inversely proportional to the light source's bandwidth. Coherence gating refers to the process of choosing a signal from a particular depth. A depth scan recording, also known as an A-scan, can be obtained in this manner. The mirror displacement limits the depth scanning range. The transverse resolution depends on the spot size, which is determined by the focusing optics 56. The morphological features of normal nails have been reported using optical coherence tomography as a diagnostic method for nail disorders. Optical coherence tomography was used to detect variations in subungual hyperkeratoses, such as inhomogeneous thickening of the ventral layer, which helped to diagnose psoriatic nail disease. Onychomycosis is an especially difficult infection to eliminate, and optical coherence tomography has proven to be an effective method for monitoring progress. In addition to clinical observation, optical coherence tomography was used to validate the efficacy of terbinafine therapy.

\section{IN-VITRO MODELS TO STUDY TRANSUNGUAL DRUG PERMEATION}

Although there has been ample research in the domain of drug delivery across the skin, however, the drug delivery across the nail is relatively less well understood. In recent years, a considerable number of novel in vitro models have been developed to determine the delivery of topical drugs applied to the full thickness of human nails. To screen formulations for antifungal activity, obtaining preliminary data for drug selection, formulation optimization the Tur Chub ZOI (zone of inhibition) assay is a semi-quantitative high-throughput method ${ }^{57}$. In this assay, the Tur Chub cell which is a modified Franz-type cell accommodates a full section thickness of human nail while maintaining a suitable seal to separate the dosing chamber from the receiver chamber. The receiver chamber is moderately filled with agar pre-seeded with the microorganism and the formulation is immediately applied to the dorsal side (surface) of the human nail to generate an agar plug on the bottom. After the nail has been treated, the cells are incubated at the appropriate temperature and time for the microbe, and the ZOI length may then be measured from the underside of the nail within the cell. Yet another model called Chub Tur EVPT (ex-vivo permeation and penetration) model, utilizes a Chub Tur cell which is a static Franz-type cell ${ }^{57}$. A section of full-thickness human nail is mounted in a Chub Tur cell and receiver fluid is sampled from the cell and analyzed to quantitate the amount of drug that has permeated across the nail. The TurSh model can use to recover and quantify the drug that has penetrated the nail. The RoMar disease activity model measures the antifungal efficacy and in-vitro bioequivalence of a formulation comprising a novel chemical component in comparison to currently marketed leading goods 57 .

\section{RECENT APPROACHES OF TRANSUNGUAL DRUG DELIVERY}

\section{Topical delivery}

Antifungal medication taken orally is inherently correlated with gastro-intestinal and systemic side effects. Topical delivery is the preferred method due to less serious side effects and improved patient compliance, particularly in pediatric patients. Unfortunately, at least two factors can restrict drug accumulation and activity in the nail after topical application. Firstly, physicochemical properties of 
drugs must be favorable for absorption through the nail matrix. According to reports, polar compounds penetrate the nail matrix more readily than nonpolar compounds. Secondly, the drugs binding to keratin limits the amount of free drug available. Antifungal drugs are said to have a high affinity for keratin 58 .

\section{Topical delivery via nanocarriers}

The topical drug delivery via nanocarriers in the treatment of nail disorders is discussed in the preceding text and highlights in Table 2.

\section{Nanoparticles}

In recent years, nanoparticles in topical/ translingual drug delivery have gotten a lot of coverage. Nanoparticles in the form of a topical medication can be applied to the nail with ease and avoid the side effects that come with oral medications. Incorporating nanoparticles increases drug targeting while also improving drug profile and permeation. Some of the nanoparticles that have been attempted to treat onychomycosis are mentioned 59 .

\section{Nanoemulsion}

Nanoemulsions are droplets of lipid and surfactant mixtures that are between 10 and $500 \mathrm{~nm}$ in size. It has all of the properties needed for antifungal therapy, including stability, improved solubilization, increased permeation effect, and targeted action. They're a great alternative to liposomes that aren't as stable 60 . Nanoemulsion therapy for onychomycosis has been the subject of a lot of studies. The nanoemulsion is sometimes distributed in the form of a gel, which is referred to as a "nanoemulgel."

Kumar et al., [2012] developed, tested, and optimized a nano-emulsion-gel of ciclopiroxolamine for the treatment of subungual onychomycosis. The formulation was created using an aqueous phase titration method and tested in a lab setting. For optimization, pseudo ternary step diagrams were created and the Box Benkhem model was used. The dependent variables were a size and zeta potential, while the independent variables were formulation components. Several nanoformulations have been developed. The longer retention capacity of the nanoemulsion-gel formulation was observed using fluorescence microscopy ${ }^{61}$. As a result, the researchers were able to create a thermodynamically stable antifungal nanoemulsion gel that carried ciclopiroxolamine and had a long retention time.

\section{Liposomes}

Liposomes are bilayered phospholipid vesicles with an aqueous heart and a phospholipid outer membrane. Liposomes are appropriate for drug delivery in both hydrophilic and hydrophobic environments. Because of their beneficial properties such as biocompatibility, improved skin penetration, durability, low toxicity, and sustained release, liposomes have been widely used in topical drug delivery applications. Liposomes and ethosomes are thought to be capable of exploiting certain lipophilic pathways in the nail, making them a promising choice for nail drug delivery. For topical antifungal treatment, some antifungal drugs have already been integrated into liposomes and ethosomes 62 .

Tanrverdi and Ozer et al., [2012] developed terbinafineloaded liposome and ethosome formulations of gel shapes. In addition to evaluation tests, in vitro and ex vivo release experiments were conducted. After applying all of the formulations, nail characterization tests revealed changes in the nail surface, with gel formulations causing the most changes. All of the formulations were found to be capable of effectively delivering terbinafine to the nail ${ }^{62}$. Furthermore, accumulation studies revealed that the liposome poloxamer gel formulation had the best results in terms of accumulation and application to the nail 63 .

\section{Nanovesicles}

Vesicular systems have long been a safe and effective way to penetrate the skin. While vesicles such as liposomes, ethosomes, and transferosomes have demonstrated their efficacy as drug delivery systems, a new class of vesicles known as penetration enhancing vesicles has also shown promise ${ }^{64}$. These nanovesicles have also been used to treat nail fungal infections through transungual delivery.

Bseisoet al., [2015] created and characterized sertaconazoleloaded nanovesicles for transungual delivery. The nanopenetration enhancing vesicles were created and characterized using various nail penetration enhancers. The chosen nano-penetration enhancing vesicles formula and the commercially available dermofix cream were compared. The optimal nail penetration enhancer for inclusion within vesicles was discovered to be $\mathrm{N}$-acetyl-L-cysteine. Sertaconazole encapsulation performance ranged from 77 to $95 \%$ in nano-penetration enhancing vesicles with a size range of $38-538 \mathrm{~nm}$. The chosen nano-penetration enhancing vesicles formula reflected a 1.4-fold increase in hydration and drug penetration into nail clippings, as well as a higher zone of inhibition 65 .

\section{Microemulsion}

The microemulsion is a thermodynamically stable carrier with low surface tension and droplet sizes ranging from 10 to 100 micrometers which have superior properties such as increased bioavailability, absorption, and permeation 66,67 .

Kansagra and Mallick et al., [2015] developed micro emulsion-based gels for the solubilization and better nail penetration of the novel anti-fungal drug Luliconazole. Olive oil as an oil, capmul MCM as a surfactant, and isopropyl alcohol as a cosurfactant were used to optimize the microemulsion. Particle size analysis, droplet size, spreadability, stability, and in vitro release studies were all performed as part of the evaluation process. The optimized batch's globule size was $32.59 \mathrm{~nm}$. The micro emulsionbased gel showed antifungal activity against Candida albicans, suggesting its effectiveness as an onychomycosis formulation 68 . 
Table 2: Nanocarriers for transungual drug delivery

\begin{tabular}{|l|l|l|l|l|}
\hline S.No. & Therapeutic molecule & Nanocarriers & Conclusion & Ref \\
\hline 1. & Ciclopirox & Nanoemulsion gel & $\begin{array}{l}\text { Nanoemulsion-based gels were found to have better } \\
\text { retention capacity. }\end{array}$ & 61 \\
\hline 2. & Fluconazole & Microemulsion gel & $\begin{array}{l}\text { Good antifungal activity against Aspergillus niger species as } \\
\text { compared to marketed commercial gel }\end{array}$ & 61 \\
\hline 3. & Clotrimazole & Liposomal film & $\begin{array}{l}\text { Formulation based on liposomal film showed greater } \\
\text { antifungal activity on fungal infected nails }\end{array}$ & 63 \\
\hline 4. & Terbinafine-HCl & Microemulsion gel & $\begin{array}{l}\text { Microemulsion-based formulation gel had greater } \\
\text { penetration, retention, and antifungal activity. }\end{array}$ & 70 \\
\hline 5. & Itraconazole & $\begin{array}{l}\text { Ethosomes } \\
\text { Bethosomes based formulation showed good antifungal }\end{array}$ & $\begin{array}{l}\text { Ethosomes } \\
\text { activity }\end{array}$ \\
\hline 7. & Sertaconazole & $\begin{array}{l}\text { Nano-penetration } \\
\text { enhacingvesicles } \\
\text { (nPEV) }\end{array}$ & $\begin{array}{l}\text { 1.4-fold increase in hydration and drug penetration into nail } \\
\text { clippings, as well as a higher zone of inhibition against } \\
\text { Trichophyton rubrum }\end{array}$ & 65 \\
\hline
\end{tabular}

\section{Nail Patch}

Nail patches can be a desired non-invasive drug carrier for topical therapy of nail diseases as a means to eliminate adverse effects of oral/injected therapies ${ }^{71}$. Post-treatment, the patch would remain at the disease site and continuously release the drug for long durations. Commercially available skin patches cannot be simply loaded with drugs for nail diseases due to the differences between the drugs and between the skin and the nail surfaces ${ }^{71}$. Nail patches have to be formulated from scratch. Assessment of the efficacy of a formulated patch against a nail disorder necessitates the use of a combination of theoretical, experimental, and modeling methods to i) identify the correct patch components, such as the adhesive, backing membrane, solvents, ii) formulate drug-loaded nail patches, and iii) evaluate the formulated patches in terms of adhesion to the nail plate, effects on nail plate hydration, drug transfer into the nail plate, and subsequent drug action against the disease. In a study, formulation of Clotrimazole nail patches using different types of polymer and gradual increase in the concentration of polymer showed good physicochemical and drug release properties ${ }^{72}$.

\section{ROLE OF PERMEATION ENHANCER IN TRANSUNGUAL DRUG DELIVERY}

Nail conditions can only be successfully treated by topical therapeutics that can penetrate through the thick keratinized nail plate and enter the deeper layers of the nail apparatus at amounts greater than the minimum inhibitory condition. Various techniques for transungual penetration enhancement, such as mechanical, physical, and chemical approaches, may be used to achieve this as discussed in the preceding text. However, successful penetration remains difficult since the nail is believed to be composed of 80-90 layers of closely bound keratinized cells, which are 100 times thicker than the stratum corneum 73. Therefore, unsatisfactory results of transungual topical therapy can be attributed to low drug permeation, high nail thickness, and long transport lag duration. Topical efficacy can be improved by mechanical, physical, and chemical modes of penetration enhancement.

\section{Mechanical methods of permeation enhancers}

Dermatologists and podiatrists have used mechanical methods of nail penetration enhancement (nail abrasion and nail avulsion) for a long time, even though they are painful and invasive.

\section{Nail abrasion}

Nail abrasion is the process of sanding the nail plate to thin it out or fully remove it. Before applying an antifungal nail lacquer, abrasion of the nails with sandpaper nail files can help to reduce the vital fungal mass and thus improve penetration. Nail abrasion thins the nail layer, exposing the contaminated nail bed and reducing the fungal mass of onychomycosis ${ }^{74}$. It can therefore improve the effectiveness of antifungal nail lacquer. For maximum effectiveness, the process may be repeated 74 .

\section{Nail avulsion}

Under local anesthesia, partial nail avulsion (surgical removal of the damaged nail plate) or total nail avulsion (surgical removal of the whole nail plate) is normally performed. Keratolytic agents (salicylic acid, urea, or a mixture of both), which soften the nail plate, have been used in clinical trials for nonsurgical nail avulsion before topical onychomycosis treatment 74 .

\section{Physical permeation enhancers}

\section{Iontophoresis}

The diffusion of charged molecules across the hydrated keratin network of a nail is improved by electric current (electromotive force), resulting in a large rise in transungual drug flux as compared to passive transport. The use of an electric field to deliver a compound through a membrane is known as iontophoresis. Iontophoresis improves drug diffusion through the hydrated keratin of a nail as opposed to passive transport. Iontophoresis greatly increased opioid penetration through the nail as compared to passive transport. With the aid of iontophoresis, the distribution of griseofulvin was increased by 8 -fold 75 .

\section{Phonophoresis}

The process of ultrasound waves being transmitted through a coupling medium onto a tissue surface is known as phonophoresis. Drug delivery enhancement could be explained by the induction of mechanical, chemical, and/or thermal changes in this tissue. On a macro level, phonophoresis can improve transcellular or pore size penetration through the stratum corneum; on a cellular level, 
pores in the cell membrane (due to lipid bilayer alteration) can improve drug diffusion 75 .

\section{Pulse laser or $\mathrm{CO}_{2}$ laser}

It demonstrates an unpredictable reaction, which could be positive. One technique is avulsion of the damaged nail section followed by $5000 \mathrm{~W} / \mathrm{cm}^{2}$ laser therapy (power density). Thus, the underlying tissue is then exposed to direct laser treatment. Another approach involves penetrating the nail plate with a $\mathrm{CO}_{2}$ laser beam, followed by regular topical antifungal treatment by laser-induced puncture holes 76 .

\section{Hydration and occlusion}

Hydration can increase the pore size of the nail matrix, making transungual penetration easier. Hydrated nails are more permeable and elastic. Iontophoretic transungual drug delivery is aided by hydration. This property is used in iontophoresis studies to improve penetration. The ionic strength and $\mathrm{pH}$ of the solution had no discernible effect on nail hydration 77 .

\section{Acid etching}

Under in-vitro conditions, surface-modifying chemical etchants $(10 \%$ phosphoric acid gel or $20 \%$ tartaric acid solution) were applied to the dorsal surface of nail clippings to alter the nail plate surface, resulting in the development of several microporosities. These microporosities improve the surface area and wettability and thereby lowering the contact angle, resulting in an optimal surface for adhering materials 78,79. Microporosities also aid in the interpenetration and bonding of a polymeric delivery system, as well as the facilitation of interdiffusion of a topical therapeutic agent. The use of the etchants described above increased the mean surface roughness by 1.3 and 1.7 times, respectively, according to atomic force microscopy 78 .

\section{Microneedles}

The use of clusters of microscopic needles is common in microneedles-based drug delivery systems. These allow the pores in the stratum corneum to open up. They also have the advantage of being so short that they do not trigger the pain fibers 80 .

\section{Low-frequency ultrasound}

The ability of low-frequency ultrasound as a physical permeation enhancer technique has been tested on entire nail plates and bovine hoof membranes. Torkar and colleagues used a 13-mm ultrasound probe held at a distance of $13 \mathrm{~mm}$ from the surface via a liquid binding medium to apply a low-frequency ultrasound $(20 \mathrm{kHz})$ to the hoof membranes as a pretreatment technique for 1 minute in a pulsatile manner. Their results indicated that ultrasoundinduced disruption of the hoof membrane resulted in increased drug permeation across the membrane. Although the exact mechanism of membrane disruption has yet to be determined, inertial cavitation or pit formation may be involved in this process 81,82 .

\section{Miscellaneous methods}

A microsurgical laser (ONYCHOLASER) unit used to create holes in tissues, especially fingernails and toenails, has been granted a patent. For the treatment of onychomycosis, antifungals are added topically to these openings 83 .

A new patent on the application of heat and/or UV light to onychomycosis-affected fingernails or toenails addresses the various devices and methodologies that can effectively provide exposure. This method involves nail heating, exposing it to UV light, and then treating it with antifungal topical therapy 84 .

5-Aminolevulinic acid-mediated photodynamic therapy is a medical procedure that involves the use of a sensitizing drug and visible light to kill cells. Donnelly et al. created a new bioadhesive patch containing 5-Aminolevulinic acid and tested its penetration through the human nail in-vitro. According to their results, if adequate concentrations of 5Aminolevulinic acid could be attained within the nail matrix and at the nail bed, photodynamic therapy could open up new vistas for onychomycosis therapy 85 .

\section{Chemical permeation enhancers}

\section{Thiols}

The agents that minimize the disulfide linkage in the keratin matrix of the nail are thiols, which are compounds containing sulfhydryl groups (-SH). A thiol is represented by R-SH. N(2-mercaptopropionyl) glycine, $\mathrm{N}$-acetylcysteine, pyrithone, mercaptoethanol, and thioglycolic acid are some of the thiols that have been used as transungual penetration enhancers 86 .

\section{Sulphites}

When proteins and peptides with disulfide bonds are incubated with sodium sulphite, the disulphide bond is cleaved, resulting in thiols and thiosulfates. As a result, it was hypothesized that incubating nail plates with sodium sulphite will lower the barrier properties of the nail plate and increase transungual drug flux ${ }^{87}$.

\section{Keratolytic enzymes}

Keratinolytic enzymes hydrolyze the keratin matrix of the nail plate, altering its barrier properties and, as a result, increasing transungual permeation ${ }^{88}$. An endopeptidase enzyme, papain with a highly reactive sulfhydryl group, has also shown a promising agent as a transungual penetration enhancer. Antifungals agents viz ketoconazole, itraconazole, and miconazole, were able to permeate the nail after 1-day incubation in papain solution (15 percent $\mathrm{w} / \mathrm{v}$ ) and 10 days of soaking in salicylic acid solution (20 percent w/v) ${ }^{88}$.

\section{Water}

On contact with water, nail hydration and swelling have been proposed as a possible mechanism for the higher drug flux from an aqueous vehicle. The permeability coefficient of C2C10 n-alkanols (but not methanol) in a saline solution was 5 times higher than that of neat alcohols 89. With the replacement of water with an organic solvent (DMSO), the permeability of hexanol (but not methanol) was reduced in a concentration-dependent way, proving the importance of water in the donor medium ${ }^{90}$.

\section{2-n-nonyl-1,3-dioxolone (SEPA)}

2-n-nonyl-1, 3-dioxolane, also known as SEPA (Soft enhancement of percutaneous absorption), is a skin penetration enhancer that has been shown to improve transdermal drug delivery 91,92 . Huiet al., investigated the distribution of econazole through the human nail using a lacquer formulation containing 2-n-nonyl-1,3-dioxolane, a penetration enhancer. A study conducted by Huiet al., revealed that adding 2-n-nonyl-1,3-dioxolane (18\%) to econazole nail lacquer (test group) increased drug delivery by six times over an equivalent lacquer composition without enhancer (control group) through the human nail. The test group had considerably higher econazole concentrations in the deep nail layer and nail bed than the control group. Furthermore, in the test group, the concentration of econazole in the deep nail layer was 14000 times higher 
than the minimum inhibitory concentration required to inhibit fungal growth ${ }^{93}$.

\section{Miscellaneous enhancers}

The transungual drug permeation across the bovine hoof membrane is increased by Polypropylene glycol 400, DMSO, Transcutol, Labrasol, N-methyl-2-pyrrolidone, and mercaptoethanol. Inorganic salts including ammonium carbonate, sodium citrate, sodiummetabisulphite, and potassium phosphate were found to increase terbinafine $\mathrm{HCl}$ drug load and drug absorption rate. Due to improved hydration of the nail plate and higher thermodynamic activity of the drug in the presence of inorganic salt, sodium phosphate was found to be the most effective inorganic salt for enhancing terbinafine $\mathrm{HCl}$ transungual permeation ${ }^{94}$.

\section{ADVANCES IN NAIL LACQUERS FOR TRANSUNGUAL DRUG DELIVERY}

For a long time, nail lacquers (enamel, varnish) have been used as a cosmetic to cover and decorate the nails. Drugcontaining nail lacquers are relatively recent formulations known as transungual delivery systems. Table 3 summarises a variety of nail lacquer-based marketed formulations 95 . These formulations comprise the drug to be administered and are organic solutions of a film-forming polymer. When the solvent is added to the nail pad, it evaporates, leaving a polymer film (containing the drug) on the plate. The drug is then gradually released from the film, penetrating the nail plate and bed. When the solvent evaporates and a film forms, the drug concentration in the film is much higher than in the initial nail lacquer ${ }^{96}$. Most notably, the medication must be released from the film for it to reach the nail. The drugcontaining polymer film can be thought of as a matrix-type (monolithic) controlled release system, with the drug being intimately mixed (dissolved or dispersed) with the polymer. Before being released, it is presumed that the dispersed drug would dissolve in the polymer film. Figure 2 depicts the drug's mechanism of action through nail lacquer. Flick's law of diffusion will control drug release from the film ${ }^{92}$. Flick's law of diffusion is given by an equation-

$$
J=D \frac{d c}{d x}
$$

where,

J- flux across a plane surface of unit area

D- diffusion coefficient

$\mathrm{dc} / \mathrm{dx}$ - concentration gradient across the diffusion path

Table 3: List of commercially available nail lacquers

\begin{tabular}{|l|l|l|l|l|}
\hline S.No. & Marketed product & Composition & Company name & Ref \\
\hline 1. & Eco nail lacquer & $5 \%$ Econazole + 15\% SEPA & Marochem Corporation, Lexington & 95 \\
\hline 2. & Umecta film & $40 \%$ Urea & JSJ Pharmaceuticals (Charleston, SC) & 95 \\
\hline 3. & Zalain patch & Sertoconazole nitrate & Labtech GmbH (Langenfeld, Germany) & 95 \\
\hline 4. & Loceryl nail lacquer & Amorolfine & ProtechBiosystem, India & 95 \\
\hline 5. & Onlyac nail lacquer & $8 \%$ Ciclopiroxamine & Dermic, Canada & 95 \\
\hline 6. & Penlac nail lacquer & $8 \%$ Ciclopiroxamine & Roche Lab, Australia & 95 \\
\hline 7. & Nailon nail lacquer & $8 \%$ Ciclopiroxamine & ProtechBiosystem, India & 95 \\
\hline 8. & Tazorac $0.1 \%$ gel & Tazarotene & Allergan Inn (Irvine, CA) & 95 \\
\hline
\end{tabular}

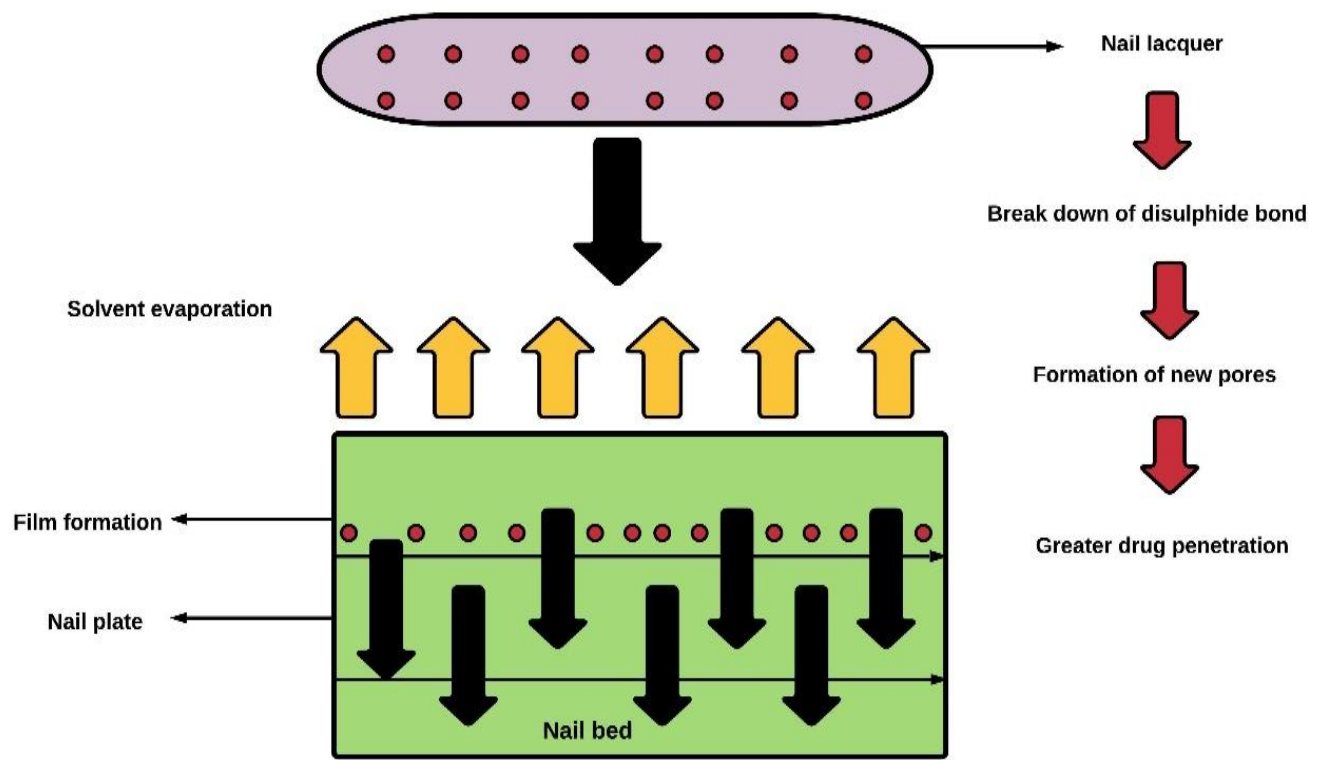

Figure 2: Drug mechanism of action through nail lacquer. 


\section{THE AVAILABLE MARKETED PRODUCTS FOR NAIL DISORDERS}

An extensive range of products has been developed for ungual and transungual delivery system. The data in Table 4 prompt a complete investigation of all key products available on market for the treatment of nail disorders.
Topical nail formulations like nail film, nail lacquer are developed by pharmaceutical industries promising a good response to the enrolled pharmaceutical market. Pharmaceutical industries are in search of newer development to produce an excellent therapeutic impact in the topical treatment of nail disorders 84 .

Table 4: Products are available on market for transungual drug delivery

\begin{tabular}{|c|c|c|c|c|}
\hline S.No. & Drug & Delivery System & $\begin{array}{l}\text { Brand } \\
\text { name }\end{array}$ & Company Name \\
\hline 1. & Amorolfine & Nail film & Loceryl & Australia Pty Ltd \\
\hline 2. & Amorolfine (5\%) & Nail lacquer & Curanil & Galderma(Lausanne, Switzerland) \\
\hline 3. & Amorolfine (5\%) & Nail lacquer & Loceryl & Roche Laboratories (Basel, Australia) \\
\hline 4. & Ciclopirox & Topical solution & Penlac & Dermik Laboratories Inc. \\
\hline 5. & Ciclopirox & Cream (1\%) & Loprox & Sanofi-Aventis (Paris, France) \\
\hline 6. & Ciclopirox & $\begin{array}{l}\text { Gel }(0.77 \%), \text { Cream } \\
(0.77 \%), \text { Solution } \\
(8 \%), \text { Topical } \\
\text { suspension }(0.77 \%)\end{array}$ & Loprox & Medicis Pharmaceutical Corp. (Scottsdale, AZ) \\
\hline 7. & Ciclopirox & Nail lacquer & Loprox & Aventis Pharma. Ltd. (Mumbai, India) \\
\hline 8. & Ciclopirox & Topical solution (8\%) & Rejuvenail & Menarini (Florence, Australia) \\
\hline 9. & Ciclopirox (8\%) & Nail lacquer & Ciclopoli & Polichem SA (Pazzallo, Switzerland) \\
\hline 10. & Ciclopiroxolamine & Cream $(0.77 \%)$ & Fougera & Fougera Pharmaceutical Inc. (Melville, NY) \\
\hline 11. & Tazarotene & $0.1 \%$ Gel & Tazorac & Allergen Inc. \\
\hline 12. & Ciclopiroxamine (8\%) & Topical solution & Onylac & Cipla (Mumbai, India) \\
\hline 13. & Ciclopiroxamine (8\%) & $\begin{array}{l}\text { Topical solution; Nail } \\
\text { lacquer }\end{array}$ & Penlac & Dermik Laboratories (Mississauga, Canada) \\
\hline 14. & $5 \%$ econazole $+18 \%$ SEPA & Nail lacquer & Eco-Nail & MacroChem Corporation \\
\hline 15. & Econazole (5\%) & Nail lacquer & EcoNail & Macrochem Corp. (Lexington, MA) \\
\hline 16. & Methyl undecenoate & Nail paint & Monphytol & LAB (UK) \\
\hline 17. & Salicylic acid & Nail paint & Phytex & Pharmax Healthcare Ltd. (Bexley, UK) \\
\hline 18. & Sertaconazole nitrate & Nail patch & Zalain & Labtec GmbH (Langenfeld, Germany) \\
\hline 19. & Sertaconazol nitrate & Nail patch & $\begin{array}{l}\text { Zalain nail } \\
\text { patch }\end{array}$ & Labtec \\
\hline 20. & Sertaconazole nitrate (2\%) & Cream & Ertaczo & OrthoNeutorgena (Los Angeles, CA) \\
\hline 21. & Tazarotene & Cream & Avage & Allergan Inc. (Irvine, CA) \\
\hline 22. & Tazarotene (0.1\%) & Gel & Tazorac & Allergan Inc. (Irvine, CA) \\
\hline 23. & Tazarotene $(0.05 \%$ \& $0.1 \%)$ & Topical gel & Zorac & Allergan Inc. (Irvine, CA) \\
\hline 24. & Ticonazole & Topical solution & Trosyl & Pfizer Ltd. (Tadworth, UK) \\
\hline 25. & Urea (40\%) & Nail film & Umecta & Jsj Pharmaceuticals (Charleston, SC) \\
\hline
\end{tabular}




\section{PATENTS REPORTS ON NAIL DISORDER TREATMENT}

Despite the reality of many clinical trial product has not reached the pharmaceutical market, transungual drug delivery has received a good number of patents. Maximum formulation shows poor permeation across nail plate, so only a few products approved for a patent. Some patents are for the methods and devices employed to increase transungual permeability. Some patents related to transungual drug delivery systems are listed in Table $5{ }^{84}$.

Table 5: Patent reports on ungual and transungual drug delivery systems

\begin{tabular}{|c|c|c|c|c|c|c|}
\hline S.No. & Investigator name & $\begin{array}{l}\text { Delivery } \\
\text { system/Therapeutic agents }\end{array}$ & Disease & Patent number & Year & Ref \\
\hline 1. & $\begin{array}{l}\text { Howard I. Maibach, Eric C. } \\
\text { Luo, and Tsung-Min Hsu }\end{array}$ & $\begin{array}{l}\text { Topical gel and cream / } \\
\text { Antifungal topical agents }\end{array}$ & Onychomycosis & $\begin{array}{l}\text { US } 006846837 \\
\text { (B2) }\end{array}$ & 2005 & 97 \\
\hline 2. & $\begin{array}{l}\text { Frank M. Kochinke, and } \\
\text { Corinne Bright }\end{array}$ & $\begin{array}{l}\text { Solution, Solid/semisolid } \\
\text { implants, Microparticles, and } \\
\text { crystals / Antifungal agents }\end{array}$ & Onychomicosis & US 0132442 (A1) & 2008 & 84 \\
\hline 3. & $\begin{array}{l}\text { Ronald Horsman, and } \\
\text { Honora Horsman }\end{array}$ & $\begin{array}{l}\text { Not specified / Antifungal } \\
\text { agents }\end{array}$ & Onychomicosis & US 0215888 (A1) & 2009 & 98 \\
\hline 4. & $\begin{array}{l}\text { Lusiana, and Christel } \\
\text { Muller-Goymann }\end{array}$ & $\begin{array}{l}\text { Thermogel / Antifungal } \\
\text { agents }\end{array}$ & $\begin{array}{l}\text { Onychomicosis, } \\
\text { Nail psoriasis }\end{array}$ & US 0010227 (A1) & 2012 & 99 \\
\hline 5. & Federico Mailland & $\begin{array}{l}\text { Nail lacquer / Antimycotic } \\
\text { agents }\end{array}$ & Onychoschizia & US 0134039 (A1) & 2006 & 84 \\
\hline 6. & Lorri Riley & $\begin{array}{l}\text { Lotion, ointment, nail polish / } \\
\text { Benzalkonium chloride }\end{array}$ & Not specified & US 7198794 (B1) & 2007 & 100 \\
\hline 7. & $\begin{array}{l}\text { Bhaskar Chaudhuri, Ming } \\
\text { Fai Chim, and Daniel Bucks }\end{array}$ & Gel / Butenafine $\mathrm{HCl}$ & Onychomycosis & US $006143794(\mathrm{~A})$ & 2000 & 101 \\
\hline 8. & $\begin{array}{l}\text { James L. Sorenson, and } \\
\text { Robert V. Petersen }\end{array}$ & $\begin{array}{l}\text { Topical solution / } \\
\text { Ciclopiroxolamine }\end{array}$ & Onychomycosis & US $005840283(\mathrm{~A})$ & 1998 & 84 \\
\hline 9. & Hans Meyer & $\begin{array}{l}\text { Topical solution and Cream / } \\
\text { Clotrimazole, Amorolfine, and } \\
\text { Terbinafine }\end{array}$ & Not specified & US 0166249 (A1) & 2007 & 102 \\
\hline 10. & Danyi Quan, and Ana Ruiz & $\begin{array}{l}\text { Nail lacquer, Solution / } \\
\text { Fluconazole }\end{array}$ & Not specified & $\begin{array}{l}\text { US } 006585963 \\
\text { (B1) }\end{array}$ & 2003 & 103 \\
\hline 11. & Marcel Nimni & Nail lacquer / Griseofulvin & Onychomycosis & US $005487776(\mathrm{~A})$ & 1996 & 104 \\
\hline 12. & $\begin{array}{l}\text { John Reginald Barrett, } \\
\text { James Joseph Brennan, and } \\
\text { Thomas Patrick Patton }\end{array}$ & Gel / Hydrogen peroxide & Onychomicosis & US 0098645 (A1) & 2010 & 105 \\
\hline 13. & $\begin{array}{l}\text { Gregor Cevc, and Ulrich } \\
\text { Vierl }\end{array}$ & Topical / Terbinafine & Onychomicosis & US 7820720 (B2) & 2010 & 106 \\
\hline 14. & $\begin{array}{l}\text { Jie Zhang, Kevin S. Warner, } \\
\text { Promod Kumar, and Hyder } \\
\text { Aliyar }\end{array}$ & Hydrogel / Terbinafine & Nail psoriasis & US 0175945 (A1) & 2009 & 107 \\
\hline 15. & $\begin{array}{l}\text { Stanley W. Kepka, Y. Joseph } \\
\text { Mo, Hang-Yong Wang, } \\
\text { Mingqi Lu, and William R. } \\
\text { Pfister }\end{array}$ & $\begin{array}{l}\text { Dual action nail coat / } \\
\text { Terbinafine } \mathrm{HCl}\end{array}$ & Onychomycosis & US 7462362 (B2) & 2008 & 108 \\
\hline 16. & $\begin{array}{l}\text { Robert W. Etheredge, } \\
\text { Dennis I. Goldberg, Shawn P. } \\
\text { Davis, Bireswar } \\
\text { Chakraborty, and Michael S. } \\
\text { Barness }\end{array}$ & $\begin{array}{l}\text { Gel (Iontophoresis) / } \\
\text { Terbinafine HCl, Fluconazole }\end{array}$ & Onychomicosis & US 0319371 (A1) & 2008 & 109 \\
\hline
\end{tabular}




\section{UNDERGOING CLINICAL STATUS OF DRUG MOLECULES OF TRANSUNGUAL DRUG DELIVERY}

Considerable advancement has been assembling in the area of clinical research and the FDA approves some transungual preparation for clinical use. Clinical trials are commenced for safe and efficacious topical formulation that could enter deep into the nails. To employ effective activity formulation must obtain therapeutic efficacy and should efficiently penetrate the nail plate 110 . Transungual formulations which are in the clinical trial phase or approved are listed in Table 6111.

Table 6: Clinical status of drug molecules for nail disorders treatment

\begin{tabular}{|c|c|c|c|c|c|}
\hline S.No. & Drug & Formulation & Clinical status & Disease & Ref \\
\hline 1. & Tazarotene & Gel & Phase IV & Nail psoriasis & 111 \\
\hline 2. & Terbinafine $\mathrm{HCl}$ & Nail lacquer & Phase III & Onychomycosis & 111 \\
\hline 3. & Amorolfine & Nail lacquer & Phase III & Onychomycosis & 111 \\
\hline 4. & $\begin{array}{l}3 \mathrm{mg} \text { terbinafine and } 2 \mathrm{mg} \text { ketoconazole } \\
6 \mathrm{mg} \text { terbinafine and } 2 \mathrm{mg} \text { ketoconazole } \\
8 \mathrm{mg} \text { terbinafine and } 2 \mathrm{mg} \text { ketoconazole }\end{array}$ & Patch & Phase I & Onychomycosis & 111 \\
\hline \multirow[t]{2}{*}{6.} & NVXT & Solution & Phase II & Onychomycosis & 111 \\
\hline & $\begin{array}{l}\text { Vegetarian Collagen } \\
\text { Keratin } \\
\text { Ceramides } \\
\text { Astaxanthin }\end{array}$ & Dietary Supplement & Phase III & $\begin{array}{l}\text { Hair Loss, skin laxity, } \\
\text { cosmetic acne nails, } \\
\text { and soft skin aging }\end{array}$ & 112 \\
\hline 7. & $\begin{array}{l}\text { Organogel of naftifine } 2 \% \\
\text { Organogel of terbinafine } 2 \% \\
\text { Organogel of naftifine } 6 \% \\
\text { Organogel of terbinafine } 6 \% \\
\end{array}$ & Gel & Phase II & Onychomycosis & 112 \\
\hline 8. & Terbinafine & Topical & Phase III & Onychomycosis & 112 \\
\hline 9. & Methotrexate & Topical & Phase II & Fingernail Psoriasis & 112 \\
\hline 10. & $\begin{array}{l}0.01 \% \text { terbinafine } / 0.03 \% \text { polyhexanide } \\
0.03 \% \text { terbinafine } / 0.09 \% \text { polyhexanide } \\
0.1 \% \text { terbinafine } / 0.3 \% \text { polyhexanide } \\
0.3 \% \text { polyhexanide } / 20 \% \text { ethanol/water }\end{array}$ & Topical & Phase III & $\begin{array}{l}\text { Distal subungual } \\
\text { onychomycosis, } \\
\text { fungal infection }\end{array}$ & 112 \\
\hline 11. & $\begin{array}{l}\text { Itraconazole } 100 \mathrm{mg} \\
\text { Itraconazole } 200 \mathrm{mg}\end{array}$ & $\begin{array}{l}\text { Capsules } \\
\text { Tablets }\end{array}$ & Phase III & Onychomycosis & 112 \\
\hline 12. & Terbinafine Gel & $\begin{array}{l}\text { ElectrokineticTransu } \\
\text { ngual System }\end{array}$ & Phase I & Onychomycosis & 112 \\
\hline 13. & Albaconazole tablet $400 \mathrm{mg}$ & capsules & Phase II & Onychomycosis & 112 \\
\hline
\end{tabular}

\section{CONCLUSION}

Although recently our understanding of topical transungual delivery and nail permeability properties has intensified considerably, yet much information is unknown like the unique fine microstructure of the nail plate, a structural mathematical model for predicting nail delivery, and drugkeratin binding properties. Disorders of the nails are common and they can be debilitating and impact the patient's ability to ambulate and perform activities. Diagnosis in most cases is confirmed on physical examination alone. Adequate biopsy techniques enable precise histopathological evaluations. The development of new human nail performance testing models will provide formulators with techniques that can be used for topical formulation development by increasing the chance that the developed product will be efficacious. The therapeutic approach to treat nail fungal infections could be achieved by a combination of topical therapy with physical or chemical enhancement methods. In addition, special precautionary steps must be taken to avoid the recurrence of the nail infection. New treatments and formulations are helping clinicians to treat nail disorders and improve patient care. However, we believe more could be done, especially for vehicles that are often not effective in the nail. In this way, a constructive approach can be offered to treat nail disorders from outside rather than inside with systemic treatments that have much more interaction with other drugs taken by the patient.

\section{ACKNOWLEDGEMENT}

Authors are thankful to Department of Pharmaceutical Sciences Dibrugarh University, Dibrugarh for proving necessary facilities.

\section{CONFLICT OF INTEREST}

The authors confirm that this article content has no conflict of interest.

\section{REFERENCES:}

1. Haneke E. Anatomy of the nail unit and the nail biopsy. , 34, 2. 2015; 34(2):95-100. DOI: 10.12788/j.sder.2015.0143

2. Wollina U, Nenoff P, Haroske G, Haenssle HA. The diagnosis and treatment of nail disorders. Deutsches Ärzteblatt International. 2016; 113(29-30):509. DOI: 10.3238/arztebl.2016.0509

3. Baswan S, Kasting GB, Li SK, et al. Understanding the formidable nail barrier: a review of the nail microstructure, composition and diseases. Mycoses. 2017; 60(5):284-295. https://doi.org/10.1111/myc.12592 
4. Murthy SN, Maibach HI. Topical nail products and ungual drug delivery: CRC press; 2012. https://doi.org/10.1201/b12896

5. Bronaugh R, Maibach H. Percutaneous Absorption: Drugs, Cosmetics, Mechanisms. Methodology. Taylor \& Francis, Boca Raton. 2005. https://doi.org/10.1201/9780849359033.ch45

6. Chouhan P, Saini T. Hydration of nail plate: a novel screening model for transungual drug permeation enhancers. International journal of pharmaceutics. 2012; 436(1-2):179182. https://doi.org/10.1016/j.ijpharm.2012.06.020

7. Verma NK, Code Q. Advance development and current challenges in nails drug delivery-A Review. https://dx.doi.org/10.7439/ijap.v6i1.3934

8. Vikas A, Rashmin P, Mrunali P, Chavan RB, Kaushik T. Mechanistic insights of formulation approaches for the treatment of nail infection: conventional and novel drug delivery approaches. AAPS PharmSciTech. 2020; 21(2):1-12.

9. Fernández-Campos F, Navarro F, Corrales A, et al. Transungual Delivery, Anti-Inflammatory Activity, and In Vivo Assessment of a Cyclodextrin Polypseudorotaxanes Nail Lacquer.

Pharmaceutics. 2020; 12(8):730.

https://doi.org/10.3390/pharmaceutics12080730

10. Tampucci S, Terreni E, Zucchetti E, Burgalassi S, Chetoni $P$, Monti D. Formulations based on natural ingredients for the treatment of nail diseases. Current pharmaceutical design. 2020; 26(5):556-565. https://doi.org/10.2174/1381612826666200122150248

11. Rigopoulos D. Anatomy and physiology of the nail unit. Nail Therapies: Current Clinical Practice. 2021:1. https://doi.org/10.1201/9781003159117-1-1

12. Haneke E. Histopathology of the nail: onychopathology. 2017. https://doi.org/10.1201/9781315184005

13. Rigopoulos D. Acute paronychia. Nail Therapies: Current Clinical Practice. 2021:10. https://doi.org/10.1201/9781003159117

14. Schwartz CT, Ezaldein HH, Merati M. Ultraviolet Light Gel Manicures: Is There a Risk of Skin Cancer on the Hands and Nails of Young Adults? The Journal of Clinical and Aesthetic Dermatology. 2020; 13(7):45.

15. Murdan S. Drug delivery to the nail following topical application International journal of pharmaceutics. 2002; 236(1-2):1-26. https://doi.org/10.1016/S0378-5173(01)00989-9

16. Cecchini A, Montella A, Ena P, Meloni GB, Mazzarello V. Ultrasound anatomy of normal nails unit with $18 \mathrm{mhz}$ linear transducer. Italian journal of anatomy and embryology= Archivio italiano di anatomia ed embriologia. 2009; 114(4):137144.

17. Farren L, Shayler S, Ennos A. The fracture properties and mechanical design of human fingernails. Journal of Experimental Biology. 2004; 207(5):735-741. https://doi.org/10.1242/jeb.00814

18. Rubin AI, Daniel CR. Simple Onycholysis and the Disappearing Nail Bed. Scher and Daniel's Nails: Springer; 2018:227-232. https://doi.org/10.1007/978-3-319-65649-6_14

19. Starace M, Alessandrini A, Piraccini BM. Yellow Nail Syndrome. Therapies for Nail Disorders: CRC Press; 2020:168-176. https://doi.org/10.1201/9780429428012-26

20. Kamrani P, Pillarisetty LS. Anatomy, Bony Pelvis and Lower Limb, Toe Nails. 2019.

21. Muddasani S, Lin G, Hooper J, Sloan SB. Nutrition and Nail Disease. Clinics in Dermatology. 2021. https://doi.org/10.1016/j.clindermatol.2021.05.009

22. Shanbhag PP, Jani U. Drug delivery through nails: Present and future. New horizons in Translational Medicine. 2017; 3(5):252263. https://doi.org/10.1016/j.nhtm.2017.01.002

23. Alavi A, Woo K, Sibbald RG. Common nail disorders and fungal infections. Advances in skin \& wound care. 2007; 20(6):346357. doi: 10.1097/01.ASW.0000276409.53632.42
24. Lipner SR. Nail Disorders: Diagnosis and Management. Dermatologic Clinics. 2021;39(2):xi. https://doi.org/10.1016/j.det.2021.01.002

25. Singh G, Haneef NS, Uday A. Nail changes and disorders among the elderly. Indian Journal of Dermatology, Venereology, and Leprology. 2005; 71(6):386. DOI: 10.4103/0378-6323.18941

26. Khanna S, Bajaj R, Khurana B, Srivastava K. Pharmacotherapeutic principles of ungual drug delivery system. Int J Drug Dev Res. 2012; 3:9-18.

27. Rajendra VB, Baro A, Kumari A, Dhamecha DL, Lahoti SR, Shelke SD. Transungual drug delivery: an overview. J Appl Pharm Sci. 2012; 2(1):203-209.

28. Poornima G, Sandhya Rani K. Nail drug delivery system-A novel approaches for drug delivery system. International Journal of Advanced Pharmaceutics. 2013; 3(2):102-109.

29. Kiran RS, Shekar BC, Vishnu P, Prasad M. Ungual drug delivery system of ketoconazole nail lacquer. Int J Appl Pharm. 2010; 4:17-19.

30. Jain G, Patel R. A comprehensive review on Transdermal drug delivery. International Journal of Pharmacy \& Life Sciences. 2019;10.

31. Muralidhar P, Bhargav E, Reddy KR. Transungual Drug Delivery: An Over View. Int J Pharma Res Health Sci. 2017; 5(1):15221528. DOI:10.21276/ijprhs.2017.01.01

32. Mathew F, Bindumol K, Paul J, Pathadan RP, Varghese V. Understanding our natural nail-Antifungal agents. Int J Pharm Pharm Sci. 2014; 6(2)

33. Patil PS, Badgujar S, Torne A. Nailing the nail trouble by transungal drug delivery. Eur J Pharma Med Res. 2015; 2(2):551-571

34. Palliyil B, Lebo DB. A novel transungual formulation (nail patch) for delivery of ciclopirox olamine into the nail and the nail folds. Int. J. Pharma Med. Biol. Sci. 2014; 3(3):13.

35. Khan AD, Giri A, Singh L. Transungual drug delivery: a newer approach. World J Pharmac. Pharmac Sci. 2014; 3(3):781-794.

36. Ohn J, Hur K, Park H, Cho S, Mun J. Dermoscopic patterns of green nail syndrome. Journal of the European Academy of Dermatology and Venereology: JEADV. 2021. DOI: $10.1111 / j d v .17224$

37. Rathi AR, Popat RR, Adhao VS, Shrikhande VN. Nail drug delivery system a review. International Journal of Pharmaceutical Chemistry and Analysis. 2020; 7(1):9-21 https://doi.org/10.18231/j.ijpca.2020.002

38. Turner R, Weaver S, Caserta F, Brown MB. A Novel Vehicle for Enhanced Drug Delivery Across the Human Nail for the Treatment of Onychomycosis. International journal of pharmaceutical compounding. 2016; 20(1):71-80.

39. Samyuktha Metta DK. Development and Evaluation of a Novel Transungual Formulation (Nail Patch) for the Treatment of Onychomycosis. 2018.

40. Murthy SN, Waddell DC, Shivakumar H, Balaji A, Bowers CP. Iontophoretic permselective property of human nail. Journal of dermatological science. 2007; 46(2):150-152. https://doi.org/10.1016/j.jdermsci.2006.12.010

41. Arrese JE, Piérard GE. Treatment failures and relapses in onychomycosis: a stubborn clinical problem. Dermatology. 2003; 207(3):255-260. https://doi.org/10.1159/000073086

42. Rich P. Principles and overview of nail surgery.

43. Grover C, Nanda S, Reddy BSN, Chaturvedi KU. Nail biopsy: assessment of indications and outcome. Dermatologic surgery. 2005; 31(2):190-194. https://doi.org/10.1111/j.15244725.2005 .31042

44. Grover C, Reddy B, Uma Chaturvedi K. Diagnosis of nail psoriasis: importance of biopsy and histopathology. British 
Journal of Dermatology. 2005; 153(6):1153-1158. https://doi.org/10.1111/j.1365-2133.2005.06862.x

45. Liaquat S, Bryson A, Mochel M. Examination Of Nail Clippings For Onychomycosis: Histologic Observations With Microbiologic Correlations. American Journal of Clinical Pathology. 2020; 154(Supplement_1):S42-S42.

46. Grover C, Bansal S. Nail biopsy: A user's manual. Indian dermatology online journal. 2018; 9(1):3. DOI: 10.4103/idoj.IDOJ_268_17

47. Reilly I. Toenail surgery: Indications, options and techniques. Dermatological Nursing. 2021;20(1).

48. Grover C, Bansal S, Nanda S, Reddy B, Kumar V. En bloc excision of proximal nail fold for treatment of chronic paronychia. Dermatologic surgery. 2006; 32(3):393-399. https://doi.org/10.1111/j.1524-4725.2006.32079.x

49. Lee KJ, Kim JE, Ahn HS, Lee YB, Park HJ, Cho BK. Proximal nail fold-Lunula double punch technique: A Less-invasive method for sampling nail matrix (초). 프로그램북 (구 초록집). 2010; 62(1):218-218.

50. Grover C, Khandpur S, Nagi Reddy BS, Uma Chaturvedi K. Longitudinal nail biopsy: utility in 20-nail dystrophy. Dermatologic surgery. 2003; 29(11):1125-1129. https://doi.org/10.1046/j.1524-4725.2003.29351.x

51. Aydin SZ, Ash Z, Del Galdo F, et al. Optical coherence tomography: a new tool to assess nail disease in psoriasis? Dermatology. 2011; 222(4):311-313. https://doi.org/10.1159/000329434

52. Bizheva K, Považay B, Hermann B, et al. Compact, broadbandwidth fiber laser for sub-2- $\mu \mathrm{m}$ axial resolution optical coherence tomography in the 1300 -nm wavelength region. Optics letters. 2003; 28(9):707-709. https://doi.org/10.1364/OL.28.000707

53. Fujimoto JG. Optical coherence tomography for ultrahigh resolution in vivo imaging. Nature biotechnology. 2003;21(11):1361-1367. https://doi.org/10.1038/nbt892

54. Serup J, Jemec GB, Grove GL. Handbook of non-invasive methods and the skin: CRC press; 2006. https://doi.org/10.3109/9781420003307

55. Sattler E, Kaestle R, Rothmund G, Welzel J. Confocal laser scanning microscopy, optical coherence tomography and transonychial water loss for in vivo investigation of nails. British Journal of Dermatology. 2012; 166(4):740-746. https://doi.org/10.1111/j.1365-2133.2011.10730.x

56. Mogensen M, Thomsen JB, Skovgaard L, Jemec G. Nail thickness measurements using optical coherence tomography and 20MHz ultrasonography. British Journal of Dermatology. 2007; 157(5):894-900. https://doi.org/10.1111/j.13652133.2007.08118.x

57. Brown M, Turner R, Wevrett SR. Use of in vitro performance models in the assessment of drug delivery across the human nail for nail disorders. Expert opinion on drug delivery. 2018; 15(10): 983-989. https://doi.org/10.1080/17425247.2018.1518425

58. Kushwaha A, Murthy RN, Murthy SN, Elkeeb R, Hui X, Maibach HI. Emerging therapies for the treatment of ungual onychomycosis. Drug development and industrial pharmacy. 2015; 41(10):1575-1581. https://doi.org/10.3109/03639045.2015.1033426

59. Luiza Ribeiro de Souza A, Priscila Kiill C, Kolenyak dos Santos F, et al. Nanotechnology-based drug delivery systems for dermatomycosis treatment. Current Nanoscience. 2012; 8(4):512-519. https://doi.org/10.2174/157341312801784311

60. Soliman GM. Nanoparticles as safe and effective delivery systems of antifungal agents: achievements and challenges. International journal of pharmaceutics. 2017; 523(1):15-32. https://doi.org/10.1016/j.ijpharm.2017.03.019
61. Kumar S, Talegaonkar S, Negi LM, Khan ZI. Design and development of ciclopirox topical nanoemulsion gel for the treatment of subungual onychomycosis. Indian Journal of Pharmaceutical Education and Research. 2012; 46(4):303-311.

62. Tanrıverdi ST, Özer Ö. Novel topical formulations of Terbinafine-HCl for treatment of onychomycosis. European Journal of Pharmaceutical Sciences. 2013; 48(4-5):628-636. https://doi.org/10.1016/j.ejps.2012.12.014

63. Tuncay Tanrıverdi S, Hilmioğlu Polat S, Yeșim Metin D, Kandiloğlu G, Özer Ö. Terbinafine hydrochloride loaded liposome film formulation for treatment of onychomycosis: in vitro and in vivo evaluation. Journal of liposome research. 2016; 26(2):163-173.

https://doi.org/10.3109/08982104.2015.1067892

64. Bsieso EA, Nasr M, Moftah NH, Sammour OA, Abd El Gawad NA. Could nanovesicles containing a penetration enhancer clinically improve the therapeutic outcome in skin fungal diseases? Nanomedicine. 2015; 10(13):2017-2031. https://doi.org/10.2217/nnm.15.49

65. Bseiso EA, Nasr M, Sammour OA, Abd El Gawad NA. Novel nail penetration enhancer containing vesicles "nPEVs" for treatment of onychomycosis. Drug delivery. 2016; 23(8):2813-2819. https://doi.org/10.3109/10717544.2015.1099059

66. Shukla T, Upmanyu N, Agrawal M, Saraf S, Saraf S, Alexander A. Biomedical applications of microemulsion through dermal and transdermal route. Biomedicine \& Pharmacotherapy. 2018; 108:1477-1494. https://doi.org/10.1016/j.biopha.2018.10.021

67. Barot BS, Parejiya PB, Patel HK, Gohel MC, Shelat PK. Microemulsion-based gel of terbinafine for the treatment of onychomycosis: optimization of formulation using D-optimal design. Aaps Pharmscitech. 2012; 13(1):184-192. https://doi.org/10.1208/s12249-011-9742-7

68. Kansagra H, Mallick S. Microemulsion-based antifungal gel of luliconazole for dermatophyte infections: formulation, characterization and efficacy studies. Journal of Pharmaceutica Investigation. 2016; 46(1):21-28. DOI 10.1007/s40005-0150209-9

69. Yadav U, Prajapati S, Prajapati R, Singh R. Development, optimization and characterization of topical nanoemulsion gel of an antifungual agent for effective treatment of onychomycosis. Pharma Research Library. 2015; 2:25-36.

70. Barot BS, Parejiya PB, Patel HK, Mehta DM, Shelat PK. Microemulsion-based antifungal gel delivery to nail for the treatment of onychomycosis: formulation, optimization, and efficacy studies. Drug delivery and translational research. 2012; 2(6):463-476. DOI 10.1007/s13346-012-0109-8

71. Bhowmik D, Gopinath H, Kumar BP, Duraivel S, Aravind G, Kumar KS. Nail Drug Delivery System-A Novel Approaches For Drug Delivery System. The pharma innovation. 2013; 1(11, Part A):3.

72. Gaddime Sonali B, Nagoba S, Pattewar Shraddha G, Wadulkar R Thonte S. Formulation and Evaluation of Medicated Nail Patches for the Treatment of Onychomycosis.

73. Hao J, Li SK. Transungual iontophoretic transport of polar neutral and positively charged model permeants: effects of electrophoresis and electroosmosis. Journal of pharmaceutical sciences. 2008; 97(2):893-905. https://doi.org/10.1002/jps.21025

74. Elkeeb R, AliKhan A, Elkeeb L, Hui X, Maibach HI. Transungual drug delivery: current status. International journal of pharmaceutics. 2010; 384(1-2):1-8. https://doi.org/10.1016/j.ijpharm.2009.10.002

75. Shemer A. 9c (iii) Onychomycosis and Iontophoresis. Onychomycosis: Diagnosis and Effective Management. 2018:141. DOI:10.1002/9781119226512

76. Yim E, Falto-Aizpurua LA, Ledon J, Nouri K. Lasers and Lights for Onychomycosis. Pediatric Dermatologic Surgery. 2019:229-240. https://doi.org/10.1002/9781118769836.ch21 
77. Hao J, Li SK. Mechanistic study of electroosmotic transport across hydrated nail plates: effects of $\mathrm{pH}$ and ionic strength. Journal of pharmaceutical sciences. 2008; 97(12):5186-5197. https://doi.org/10.1002/jps.21368

78. Mididoddi PK, Repka MA. Characterization of hot-melt extruded drug delivery systems for onychomycosis. European Journal of Pharmaceutics and Biopharmaceutics. 2007; 66(1):95-105. https://doi.org/10.1016/j.ejpb.2006.08.013

79. Repka MA, O'Haver J, See CH, Gutta K, Munjal M. Nail morphology studies as assessments for onychomycosis treatment modalities. International journal of pharmaceutics. 2002; 245(1-2):25-36. https://doi.org/10.1016/S03785173(02)00321-6

80. Basini P, Kr DB, Sudip D, Subhas S. Nail drug delivery system: a review. Journal of advanced Pharmacy education \& research. 2012; 2(3):101-109.

81. Torkar A, Kristl J, Murdan S. Low-frequency ultrasound to enhance topical drug delivery to the nail. 2007.

82. Mitragotri S, Kost J. Low-frequency sonophoresis: a review. Advanced drug delivery reviews. 2004; 56(5):589-601. https://doi.org/10.1016/j.addr.2003.10.024

83. Karell ML. Laser apparatus for making holes and etchings: Google Patents; 1999.

84. Saner MV, Kulkarni AD, Pardeshi CV. Insights into drug delivery across the nail plate barrier. Journal of drug targeting. 2014;2 2(9):769-789.

https://doi.org/10.3109/1061186X.2014.929138

85. Donnelly RF, McCarron PA, Lightowler JM, Woolfson AD. Bioadhesive patch-based delivery of 5-aminolevulinic acid to the nail for photodynamic therapy of onychomycosis. Journal of controlled release. 2005; 103(2):381-392. https://doi.org/10.1016/j.jconrel.2004.12.005

86. Malhotra GG, Zatz JL. Investigation of nail permeation enhancement by chemical modification using water as a probe. Journal of pharmaceutical sciences. 2002; 91(2):312-323. https://doi.org/10.1002/jps.10058

87. Murdan S. Enhancing the nail permeability of topically applied drugs. Expert opinion on drug delivery. 2008; 5(11):1267-1282. https://doi.org/10.1517/17425240802497218

88. Quintanar-Guerrero D, Ganem-Quintanar A, Tapia-Olguin P, Kalia YN, Buri P. The effect of keratolytic agents on the permeability of three imidazole antimycotic drugs through the human nail. Drug development and industrial pharmacy. 1998; 24(7):685-690. https://doi.org/10.3109/03639049809082373

89. WALTERS KA, FLYNN GL, MARVEL JR. Physicochemical characterization of the human nail: permeation pattern for water and the homologous alcohols and differences with respect to the stratum corneum. Journal of Pharmacy and Pharmacology. 1983; 35(1):28-33. https://doi.org/10.1111/j.2042-7158.1983.tb04258.x

90. Monti D, Saccomani L, Chetoni P, Burgalassi S, Saettone M, Mailland $\mathrm{F}$. In vitro transungual permeation of ciclopirox from a hydroxypropyl chitosan-based, water-soluble nail lacquer. Drug development and industrial pharmacy. 2005; 31(1):11-17. https://doi.org/10.1081/DDC-43935

91. Baran R, Tosti A. Chemical avulsion with urea nail lacquer. Journal of dermatological treatment. 2002; 13(4):161-164. https://doi.org/10.1080/09546630212345672

92. Morganti F, Bramanti E, Solaro R, et al. Thermal and spectroscopic characterization of interactions between 2-nonyl1, 3-dioxolane and stratum corneum components. Journal of bioactive and compatible polymers. 1999; 14(2):162-177. https://doi.org/10.1177\%2F088391159901400205
93. Hui X, Chan TC, Barbadillo S, Lee C, Maibach HI, Wester RC. Enhanced econazole penetration into human nail by 2-n-nonyl1, 3-dioxolane. Journal of pharmaceutical sciences. 2003; 92(1):142-148. https://doi.org/10.1002/jps.10291

94. Nair AB, Sammeta SM, Vaka SRK, Murthy SN. A study on the effect of inorganic salts in transungual drug delivery of terbinafine. Journal of Pharmacy and Pharmacology. 2009; 61(4):431-437. https://doi.org/10.1211/jpp.61.04.0003

95. Aggarwal R, Targhotra M, Kumar B, Sahoo P, Chauhan MK. Novel Polypseudorotaxanes Hydrogel based Nail Lacquer of Efinaconazole for Transungual Drug Delivery. Drug Delivery Letters. 2021; 11(1):52-61. https://doi.org/10.2174/2210303110999200918163213

96. Shivakumar H, Repka M, Murthy SN. Transungual drug delivery: an update. Journal of Drug Delivery Science and Technology. 2014; 24(3):301-310. https://doi.org/10.1016/S17732247(14)50049-4

97. Maibach HI, Luo EC, Hsu T-m. Topical administration of basic antifungal compositions to treat fungal infections of the nails: Google Patents; 2005.

98. Jagat S, McKay D. Topical nail formulation: Google Patents; 2009.

99. Müller-Goymann C. Formulation for nail and nail bed diseases: Google Patents; 2012.

100. Riley L. Topical formulation for treating fingernails and toenails: Google Patents; 2007.

101. Chaudhuri B, Chim MF, Bucks D. Topical formulations for the treatment of nail fungal diseases: Google Patents; 2000.

102. Meyer H. Pharmaceutical and cosmetic formulations for treating fingernails: Google Patents; 2007.

103. Quan D, Ruiz A. Nail compositions and methods of administering same: Google Patents; 2003.

104. Nimni M. Anti-fungal nail lacquer and method therefor: Google Patents; 1996.

105. Barrett JR, Brennan JJ, Patton TP. Formulation and method for the treatment of fungal nail infections: Google Patents; 2016.

106. Cevc G, Vierl U. Topical terbinafine formulations and methods of administering same for the treatment of fungal infections: Google Patents; 2010.

107. Zhang J, Warner KS, Kumar P, Aliyar H. Systems, methods, and formulations for topically treating nail fungal infections and nail psoriasis: Google Patents; 2009.

108. Kepka SW, Mo YJ, Wang H-y, Lu M, Pfister WR. Antifungal nail coat and method of use: Google Patents; 2008.

109. Etheredge RW, Goldberg DI, Davis SP, Chakraborty B, Barsness MS. Method and system for treating of onychomycosis with an applicator having a gel medicament layer: Google Patents; 2008.

110. Sakamoto M, Sugimoto N, Kawabata H, et al. Transungual delivery of efinaconazole: its deposition in the nail of onychomycosis patients and in vitro fungicidal activity in human nails. Journal of drugs in dermatology: JDD. 2014; 13(11):1388-1392.

111. Gupta AK, Simpson FC. New pharmacotherapy for the treatment of onychomycosis: an update. Expert opinion on pharmacotherapy. 2015; 16(2):227-236. https://doi.org/10.1517/14656566.2015.993380

112. Gupta AK, Studholme C. Novel investigational therapies for onychomycosis: an update. Expert opinion on investigational drugs. 2016; 25(3):297-305.

https://doi.org/10.1517/13543784.2016.1142529 